\title{
Resmi gıda kontrollerinde Covid-19 tedbirlerine yönelik ilave gereklilikler
}

\author{
Sibel Özçakmak' ${ }^{1}$ (a) \\ ${ }^{1}$ Atakum Tarım ve Orman Illçe Müdürlüğü, Samsun, Türkiye
}

Sayın Editör,

Covid-19 tedbirlerinin Ek.4 Onaylı/Kayıtlı İşletmelere Ait Resmi Kontrol Formuna dâhil edilmesi her iki kanunun uygulanabilirliğinin kontrolü ve idari yaptırımlar açısından önemli kolaylıklar sağlayacağını düşündüğüm “Resmi Gıda Kontrollerinde Covid-19 tedbirlerine Yönelik illave Gereklilikler" başlıklı çalışmamla ilgili bazı görüşlerimi paylaşmak istiyorum.

Bireysel ve sosyal hayatlarımız üzerinde ani ve beklenmedik etkilere yol açan pandemi döneminde, salgının/ bulaşın toplum sağlığı ve kamu düzeni açısından oluşturduğu riski yönetme, sosyal izolasyonu temin, sosyal mesafeyi koruma ve salgının/bulaşın yayılım hızını kontrol altında tutma amacıyla birçok tedbir kararları alınarak uygulamaya geçirilmiştir. Dünya Sağlık Örgütü, virüsün bulaşması ve yayılmasının engellenmesi için kamuoyuna yönelik genel tavsiyeler yayınlamıştır. Ülkemizde de bu doğrultuda, hayatın her alanına yönelik uyulması gereken kurallar ve önlemler; Sağlık Bakanlığı ve Koronavirüs Bilim
Kurulunun önerileri, Cumhurbaşkanı talimatları doğrultusunda belirlenerek uygulamaya geçirilmektedir.

Kamu otoritelerinin Covid-19'u önlemeye yönelik kurallarının çoğu genel hijyen ilkelerine dayanmaktadır. İşletme yetkilileri ve çalışanları, faaliyette oldukları sürece Yeni Koronovirüs hastalığına karşı işyerlerinde etkin mücadele için kamu otoritesi tarafından bildirilen tedbirlere uymak zorundadır. Gıda işletmelerinin pandemi sürecinde 5996 sayılı Veteriner Hizmetleri Bitki Sağlığı Gıda ve Yem Kanunu'na ve 1593 sayılı Genel Hijyen Kanununa (Umumi Hıfzıssıhha Kanunu) uyması gerekmektedir. Denetim ve kontrollerde gıda operasyonlarının emniyetli koşullarda sağlanması, belirlenen kontrol önlemlerinin alınması ve tüm bu işlemlerin sürekliliği hedeflenmektedir. Resmi incelemelerde sadece gıda güvenliği kriterleri değil, Covid-19 hastalığının yayılmasını önlemek için ek önlemler de dikkate alınmaktadır (Anonim 2010; Anonim, 2011; Anonim, 2020). Bu öngörü ile Onaylı/Kayıtlı İşletmelere Ait Resmi Kontrol Formu'na yapmış olduğum ilaveler, bilgilerinize sunulmuştur. Önümüzdeki dönemlerde bir katkı olarak değerlendirilmesini ümit ediyorum.

Çizelge 1. Resmi Gıda Kontrollerinde Covid-19 tedbirlerine Yönelik Ilave Gereklilikler

\section{A. GENEL HIJYYN}

1. Koronavirüs tedbirleri kapsamında işletmelerin faaliyet öncesi, mola sonrası ve faaliyet bitiminde temizlik ve dezenfeksiyon işlemlerinin uygulanmalı, bu işlemler günlük olarak kaydedilmelidir.

2. Personeller arasındaki sosyal mesafenin korunacağı ve personelin mümkün olduğu kadar az kişi ile temas sağlayacağı bir çalışma düzenine geçilmeli, Koronavirüs tedbirleri kapsamında işletmelerin alanı sosyal mesafe ( en az 2 metre) kuralına uygun olacak şekilde olmalı. Bulaşık alandan temiz alana mekanik hava akımı önlenmeli, \%100 temiz havanın sirkülasyonu sağlanacak şekilde havalandırma sağlanmalı, havalandırma sisteminin filtrelerin temizliği, bakım-onarımı periyodik olarak yapılmalıdır.

3. Depo yeterli kapasitede olmalı, yeterli havalandırma sağlanmalı, gerekli durumlarda sıcaklıkların izlenmesini ve kayıt edilmesini sağlamalıdır. Havalandırma, Covid-19 Kapsamında Klima/iklimlendirme Sistemlerinde Alınacak Önlemlere uygun olmalıdır.

4. Drenaj sistemi, bulaşma riskini önleyecek şekilde oluşturulmalı, drenaj sistemleri çevreye zarar vermemeli, yeterli sayı ve boyutta drenaj kanalı bulunmalı, atık su kanalları zararlı girişine, koku yayılmasına ve atıkların kanaldan geri dönüşüne karşı güvenilir, temizlenebilir-dezenfekte edilebilir olmalıdır.

5. İşletmenin girişinde dezenfektanlı paspas ve her bölümünde yeterli sayıda lavabo ve el dezenfektanı bulundurulması, işletmede varsa banyolar ve tuvaletlerin Sodyum Hipoklorit ile düzenli olarak dezenfeksiyonu sağlanmalı, atık su borularında kaçak, çatlak, vb. tespit edilerek onarılmalı, kanalizasyon sistemi dışına yayılması engellenmelidir.

6. Lavabo girişlerine dezenfektan paspas, sıcak ve soğuk akan su, el temizleme ve dezenfeksiyon malzemeleri, tek kullanımlık kağıt havlu bulundurulmalıdır.

7. Gıda yıkama bölümleri, el yıkama bölümlerinden ayrı olmalıdır. Gıda yıkama bölümünde sıcak akan su ve yeterli sayıda ve büyüklükte yıkama havuzları bulundurulmalı, gıdaların yıkanmasında kullanılan su güvenilir olmalıdır.

9. Drenaj sistemi, ön arıtma işleminden sonra deşarj noktasından önce dezenfeksiyon işlemine tabi tutulmalı, su ve atık su yönetimleri oluşturulmalıdır.

10. Soyunma odalarında, yemekhanede, servislerde, sosyal mesafenin korunması için gerekli önlemleri alınması sağlanmalıdır.

11. Temizlik ve dezenfeksiyon maddeleri gıdanın bulunduğu alanlarda depolanmamalıdır.

12. İşletme İçi Salgın Tedbir Planı hazırlanmalıdır.

B. ÖZEL HIJJYN GEREKLILIKLERi

1. Corona virüsünün yüzeyde tutunma süreleri dikkate alınarak günlük temizlik-dezenfeksiyon işlemleri uygulanmalı ve kaydedilmelidir.

2. Tavan yüksekliği, çalışılan alanın $m^{2 \prime}$ sine uygun havalandırma sağlamalıdır. 
3. Kapılar temizlenebilir, dezenfeksiyona uygun, pürüzsüz ve emici olmayan malzemeden üretilmiş olmalı, günlük olarak temizlik-dezenfeksiyon işlemi yapılmalı ve kaydedilmelidir.

4. Tüm yüzeyler günlük olarak en geç 2 saatte 1 kez olmak üzere temizlik-dezenfeksiyon işlemi yapılmalı ve kaydedilmelidir. Pazar yerleri ile ilgili gereklilikler

1. Mevcut pazar yerlerinde ve yoğunluğu dağıtmak için belirlenen yeni pazar/satış yerlerinde her bir satış yeri (tezgah/sergi) arasında en az 3 metre mesafe olacak şekilde pazar/satış yerlerinin düzenlenmesi, pazar/satış yerlerinde ambalajsız satılan yaş sebze ve meyvelerin tüketicilerce temas edilmeden, doğrudan pazarcı esnafı tarafından hijyen koşullarına dikkat edilerek poşetlenmesi/satışı yapılmalıdır.

2. Bu yerlerde çöp toplama (gıda ve tıbbi atık), hijyen ve dezenfeksiyon hususunda gerekli tedbirler alınmalıdır.

3. Kişisel hijyen kurallarına uyması konusunda gerekli koruyucu önlemlerin alınması (maske, eldiven, bone vb.), el dezenfektanı bulundurulmalıdır.

C. TAŞıMA

1. Taşımada kullanılan araçların özellikle fazla temas edilen yüzeyler başta olmak üzere sık aralıklarla (en geç iki saatte bir) temizlik-dezenfeksiyonı sağlanmalıdır.

D. EKIPMAN ILE ÍgiLi GEREKLILIKLER

1. Kullanılan dezenfektan maddenin uygulanacak yüzeye spesifik olması, korozif etki göstermemesi ve etki spektrumunun tüm mikroorganizmaları kapsayacak şekilde (bakteri, maya-küf, virüs vb.) olması sağlanmalıdır.

2. Temizliği yapan kişi yaptığı işlemin kaydını tutmalı, uygulama sırasında maske ve diğer koruyucu tedbirler sağlanmalıdır.

\section{E. TIBBi ATIK YÖNETiMi}

Covid-19 pandemisine yönelik atık yönetim (tıbbi, evsel, diğerleri) sistemi oluşturulmalı, maske-eldiven-diğer koruyucu ekipmanları içeren kontamine olmuş atıklar üzerleri örtülebilen kaplar içinde toplanmalı, 500 mg/L olan klor içeren bir dezenfektan ile muameleden sonra, ağzı kapalı bir poşet içinde tehlikeli çöplere atılmalıdır.

\section{F. SU TEDARIKi}

1. Merkezi su arıtma yöntemleri tüm bulaşıcı hastalık etmenlerini inaktive edecek şekilde kurulmalı, işletmede su güvenliği sağlanmalıdır

\section{G. PERSONEL HIJYENi}

1. Solunum yolu enfeksiyonu bulguları gösteren kişilerin bireysel izolasyonu sağlanmalı, son 14 gün içinde Koronavirus teşhisi konmuş herhangi biriyle temas ettiyse bunu gıda işletmesine bildirmeli, gıda işletmesine gitmeyip kendisine ev karantinası uygulanmalıdır.

2. Bütün personel ağız ve burnu kapatacak şekilde tıbbi maske kullanmalı, ortak kullanım alanlarında maskeye temastan sonra el hijyeni sağlanmalıdır.

3. Olası bir bulaşı ortaya çıkması ya da şüphesi halinde iletişim ve acil durum senaryosu hazırlanmalıdır. İşletmede "Acil durumda ulaşılacaklar listesi ve iletişim bilgileri" güncel tutulmalıdır.

4. Gıda işletmesine giren herkesin, basit bir formla sağlık/seyahat anket kaydı tutulmalı ve dijital termometre ile ateşi ölçülmelidir.

5. Soyunma odalarında, yemekhanede, servislerde, sosyal mesafenin korunması için gerekli önlemler alınmalıdır.

6. İşletmenin girişinde ve her bölümde yeterli sayıda el dezenfektanı bulundurulmalıdır.

7. Personelin kullandığı kirli maske-eldiven vb için uygun tıbbi atık prosedürü uygulanmalıdır.

8. Gıda ile temas halinde çalışan tüm personelin herhangi bir bulaşıcı hastalık taşımadığına dair sağlık raporu beyan edilmeli, düzenli sağlık kontrolü yapılmalıdır. Bulaşıcı hastalık açısından izlenebilmesi için personelden periyodik bilgi (HES kodu gibi) alınmalıdır.

9. İşletmenin Salgın Yönetiminden sorumlu personel bulundurulmalıdır.

10. Gıda ile taşınabilen bir hastalığı olan veya bu hastalığın taşıyıcısı durumundaki personelin, gıda ile temas etmesine veya gıdaların işlendiğ alanlara girmesine izin verilmemelidir.

11. İşletmede temizlik ve personel hijyeninden sorumlu kişi veya kişiler bulunmalıdır.

12. Bulaşıcı hastalıklarla mücadele döneminde aynı vardiyada aynı personel çalıştırılmalıdır.

\section{H. GIDALARIN AMBALAJLANMASINA VE PAKETLENMESINE İLiŞKIN HÜKÜMLER}

1. Yeni tip koronavirüsün yüzeylerde tutunması süreleri (3 saat ile 5 gün arası) ambalajlama ve paketlemede kullanılan materyalin bulaşma kaynağı olmaması için gerekli tedbirle alınmalıdır. Depo ortamı sık sık havalandırılmalıdır.

2. Ambalaj materyali, bulaşma riskine maruz kalmayacak biçimde korunaklı halde depolanmalı, çapraz bulaşmalara karşı önleyici tedbirler alınmalıdır.

\section{EĞiтiM}

1. Gıda işinde çalışan personelin yaptıkları işin gerektirdiği gıda hijyeni ve Bulaşıcı Hastalıklarla Mücadele konularında belirli aralıklarda bilgilendirme ve eğitimleri sağlanmalı, mutlaka bir" Kriz Yönetimi Ekibi" oluşturulmalı, bu ekip tarafından süreçte gerekli olacak kişisel koruyucu ekipman ve hijyenik malzeme miktarı ve stok düzenli olarak gözden geçirilmelidir.

2. Çalışanların bilinçlenmesi, kuralların uygulanması ve çalışma ortamının iyileştirilmesi için gıda hijyeni ve pandemiye ilişkin afiş ve broşürler bulundurulmalıdır.

3. Gıda İşletmesinde çalışan personelin "Gıda Hijyeni" konusunda Eğitim Sertifikası bulunmalıdır.

\section{Referanslar}

Anonim. (2010) Veteriner Hizmetleri, Bitki Sağlığı, Gıda ve Yem Kanunu, Kanun No: 5996, Kabul No: 11/06/2010. Resmi Gazete Sayısı: 27610. Erişim adresi: http://www.resmigazete.gov.tr/ eskiler/2010/06/20100613-12.html, Erişim Tarihi: 26.09.2017.
Anonim. (2011) Gıda Hijyen Yönetmeliği. Erişim adresi: https:// www.resmigazete.gov.tr/eskiler/2011/12/20111217-5.htm, Erişim Tarihi: 15.02.2013.

Anonim. (2020) Covid-19 Salgın yönetimi ve çalışma rehberi. Bilimsel Danışma Kurulu çalışması. Erişim adresi: https://covid19.saglik.gov.tr/Eklenti/38700/0/Covid19salginyonetimivecalismarehberipdfpdf.pdf, Erişim Tarihi: 01.08.2020. 